\title{
The Urgency of Child Protection in Realizing Cities Child Based: Concept and Manifestation
}

\author{
Fransiska Novita Eleanora $^{1^{*}} \quad$ Edy Supriyanto ${ }^{2}$ \\ 1. Department of Law, Law Program, Bhayangkara University, Jakarta 12550, Indonesia \\ 2. Department of Law, Law Program, MPU Tantular University, Jakarta 13410, Indonesia
}

\begin{abstract}
Protection of children is an activity that can provide guarantees and protect children and their rights so that they can always live, grow and develop optimally and participate in accordance with the dignity and dignity of humanity and get protection from violence and discrimination. Protection of the existence of children's rights is part of the rights of a child who must be protected since the child is in his mother's womb, so that he is born into the world in a healthy condition without any shortcomings, because children are part of the struggle and successor to the ideals of the nation. Its protection is not only the responsibility of the parents but also the Government, the State, the Law, the Community, because of the importance of protection for children, the Government established a program on city policies that are child-friendly with existing goals and concepts, namely prioritizing children's rights and also based on the existence of child friendly, which can be explained that a city that is suitable for children prioritizes children for their daily needs. But apparently in its manifestation there are still many obstacles or obstacles in the implementation of the city which is called child-worthy.
\end{abstract}

Keywords: protection, child, city

DOI: $10.7176 / \mathrm{JLPG} / 109-06$

Publication date:May $31^{\text {st }} 2021$

\section{Introduction}

Protection of children's rights has become the responsibility of all stakeholders, because children are human beings and the successors of the generation and aspirations of the struggle of the nation, besides that recognition of the protection of human rights and the rights of a child has been regulated in writing in the year law. 1999, number 39 regarding Human Rights. The law states that human rights are a gift from God Almighty, and the State recognizes and even upholds and everyone respects and respects them, therefore recognition and protection of the existence of the human rights of children has been protected by the Government and also the State. Due to the importance of protecting children, there is recognition and enforcement of their human rights, so that children become a serious and special concern in people's lives, because of that seriousness from the Government of Indonesia, issuing a policy that does not only discuss child protection, but also concerns child protection. a place or area that can provide a safe and comfortable feeling for children to live in, and provide a sense of shade and away from matters relating to crimes and violations from the reach of children (Waluyadi, 2009)

The basis for the formation of a district or city that is suitable for children is due to the fulfillment of children's basic needs and because of the Indonesian State Committee to ratify the convention on children's rights, namely in September 1990 on the 5th, as outlined in the 1945 Constitution Article 28 (B) 2 and its operation or implementation is stated in Law Number 35 of 2014 concerning Amendments to Law Number 23 of 2002 concerning Protection of Children. The formation of a child-friendly city is very much aimed at prioritizing children's rights and the best interests of the child, and is in line with and implementing the definitions, and strategies, as well as programs related to child-friendly cities and policies from institutions.

The naming of cities that are suitable for children was first introduced in 2005 by the Ministry of Women's Empowerment with various names, namely cities that are child-friendly or child-friendly. Protection for children that has been running is not only implemented in cities, but also in districts, this shows that there are efforts to promote the welfare of children, educate the nation's life, by involving the community to participate and actively support activities in improvement, and the existence of services., as well as empowerment, as well as enhancement of regional competitiveness by taking into account every principle of democracy, equity, as well as justice, as well as privileges and specificities within a region within a system of the Unitary State of the Republic of Indonesia.

The name of a city that is suitable for children was first introduced in 2005 by the Ministry of Women's Empowerment with various names, namely a city that is child-friendly or child-friendly. Protection for children that has been running is not only implemented in urban areas, but also in districts, this shows that there are efforts to promote the welfare of children, educate the nation's life, by involving the community to participate and actively support activities in improvement, and service, as well as empowerment, as well as enhancement of regional competitiveness by taking into account every principle of democracy, equity, as well as justice, as well as privileges and peculiarities within a region within a system of the Unitary State of the Republic of Indonesia. 
Based on the above introduction, the authors are interested in examining the problems regarding the urgency of child protection in realizing a child-based city; its concept and manifestation.

\section{Research Methods}

This study uses juridical normative, which is based on books as well as laws and regulations in relation to the problems to be analyzed in this study.

\section{Results And Discussion}

The notion of children in general can be interpreted as immature in terms of their psychological aspects as well as referring to their age and ability to act and children also still need help from other people, especially in their families, namely their parents provide protection to them in the aspects of their environment and place of residence, even the definition of the child also refers to the age limit, which is not yet between eighteen years old, including in the womb. It is explicit that since a child is in a woman's womb, her rights have been protected, especially her right to live, and be healthy and protected until adulthood, protection of children's rights is part of upholding and recognizing the rights of a child to develop to get a life and prosperity. proper to be good where the child is, especially in the environment where he lives and where he studies so that later he becomes a child who has good character, and is based on noble character and be based on noble character and become a child of faith.

Child protection is defined as a series of activities to ensure and prevent children from being protected from acts of violence, exploitation and abuse, in that the protection of children is based on an approach based on the existing system, namely: the system of effective protection and protects children from all forms of violence as well as wrongdoing, neglect, and exploitation, protection from children that is effective and requires components that are also interrelated and services along with a series of child protection starting from primary, secondary and tertiary prevention in the community aspect (Fitriani, 2016)

It is called a city that is based on being worthy of being worthy because all prioritize and prioritize the rights of children, where in its implementation there are no longer neglected children's rights, all children have got their rights and have realized the welfare of children. The assessment of the city which is considered to reflect the existence and prioritization of the rights of children is based on several indicators, namely the existence of commitment and integration as well as from the government and its resources, as well as the community, as well as the existence of a business world which is considered to have been planned in a sustainable and comprehensive manner in every policies, programs, and various activities to ensure the fulfillment of the protection and rights of children (Saraswati, 2007)

The rights of children referred to as stated in the Convention on the rights of UN children in 1989, as well as various laws and regulations, namely:

a) The right to always play, playing can be a child's entertainment in filling free time, playing can also be interpreted as channeling talents and hobbies, because playing can also be done by exercising, such as playing football, volleyball and so on, children should not be restrained from always learning and learning, but Besides studying, they are given time to play or do their daily activities and routines.

b) There is the right to always have access to education is very important for children, so that children can instill an insight into a future that is very bright and is part of human rights, so that by learning, children can find the meaning of their identity so that they can always get better goals. of course in getting a decent job.

c) The right to always have protection of the existence of dangers that will threaten the safety of children, protection can also be interpreted as placing the child in a comfortable and safe condition, away from all dangers from acts of violence, discrimination or those that would violate the rights of the child.

d) There is the right to always get a name (identity), the provision of identity for citizens or children can be done through a birth certificate, and is a form of recognition of the child

e) There is a right to always have status and also nationality, the national status given to children is also part of human rights with status and nationality giving clarity to the child including which nationality and will have an impact on the protection that will be given to the child, if the child is in conflict with the law or as a victim, including in terms of rights. ownership or other rights, with this status there is a legal remedy that is obtained by a child.

f) The right to always have food, or nutrition given to children is closely related to their right to life, intake of vitamins and food will provide growth for children, become adults and do not cause food or nutritional deficiencies, because good food and nutrition will result in good growth and development.

g) The right to always have access to health is also a part of necessity, which is very important because in the provisions of the 1945 Constitution in Article $28 \mathrm{H}$ paragraph 1, it is stated that everyone or anyone has the right to always live in prosperity, physically and mentally, residing and getting life which is proper, also healthy and has the right to get health, including here is a healthy and clean environment for growth and development for children, away from garbage waste so as not to cause disease for children. 
h) There is a right to always have recreation is carried out to eliminate boredom, because they have to carry out activities such as learning or tutoring, so that entertainment is needed to relieve fatigue, and recreation can also relieve children's stress, build a sense of love and affection for the family, children can interact with the environment other social

If you hear a city that is suitable for children, of course, it feels like it is intended for children, namely peace and welfare of children, prioritizing all children's needs and the best things for the sake of children. The concept of the child is also based on the existence of government initiatives to lead to all efforts to transform the rights of children. The need for realizing a city that is truly child-worthy (KLA), because children are the generation and successor who will come and also carry on the aspirations and struggles of a nation, besides that the need for the quality of the self of an child does not become a burden in a development, and in implementing this concept always coordinate with related parties so that it is always sustainable, also integrated and holistic (Joni \& Zulchaina, 1999)

Children as an inseparable part and having their rights are not only the concern of the Indonesian people, but almost all countries declare the protection of the rights of children, and on that basis the concept of a decent city is formed, with a commitment at an international level. namely World Fit For Children (WFC), where there are several areas of special concern regarding children, namely, (i) Promotion of health in life, (ii) Provision of quality education, (iii) Protection of any treatment or action either because of exploitation, as well as violence, or also mistreatment in educating children, and (iv) HIV / AIDS virus or disease prevention is carried out (Haq, 2016)

In addition, there are several clusters that must be fulfilled, in determining the cities that are considered appropriate for children in the fulfillment and protection of children's rights and the needs of children, namely;

Cluster 1, concerning civil rights and freedoms. Children must have their rights to get their own identity, including services for free birth certificates free of charge. In addition, information is accurate and deserves the right to be obtained by children.

Cluster 2, concerning the family environment and childcare. This cluster dominates the care and protection in the family realm, including adopted or adopted children, who must comply with regulations, and are always monitored and evaluated so that the child's growth and development can run properly and the child's interests are met.

Cluster 3, on the existence of basic health and welfare in children. Health services provided to children should not occur or be infected with malnutrition and hunger edema because they are deemed to lack essential protein, such as carbohydrates, protein and fat, as well as vitamins and minerals. So that it must be considered since the fulfillment of the nutrition of a pregnant mother and the health of a child when she is growing in her body. Apart from that, the provision of proper service to posyandu and puskesmas for children is a major concern.

Cluster 4, getting a really decent education, with the use of very spare time as well as activities in culture. As in the implementation of the 12 year compulsory education, it means getting a really decent education with adequate facilities and infrastructure or access without any discrimination.

Cluster 5, Special protection. Among them, handling where children are confronted with child refugees or in situations of armed conflict, actions that must be taken to save children and fulfill their life needs and eliminate the sense of trauma, psychology resulting from the incident, or exploitation both economically or sexually, the occurrence of trafficking. Humans through conventional crimes or online, which target children to be sold, recruited and trafficked must receive very special protection as well as children with special needs, namely children with disabilities, having disabilities, disabilities. They also have the right to get the right to education, health, develop their talents and hobbies, not because they have a disability and are then hidden away or deliberately discriminated against, because after all they are children who have the same existence and fulfillment of rights as others (Holzscheite, 2019)

The implementation of a child-friendly city already reflects that the city puts forward all the fulfillment of children's rights, and it takes a very long concept, and to make a city called child-friendly there must be coordination and commitment from various stakeholders to jointly agree to integrate every development. in the territory for the sake of being used for the needs and fulfillment of the rights of the child. Where the stakeholders in question are the government, society and also the business world; integration with resources consisting of reliable human resources who also care and are sensitive to children, prioritizing everything that is best for children and the availability of adequate facilities and infrastructure in accordance with the needs of the child, as well as the budget used in a sustainable development process to fulfill everything needed; as well as integration into various existing policies, as well as programs and activities in support of any urban development for and in ensuring the fulfillment of all rights of children. (Setyawati, 2019)

The appointment of a city that is intended for children, in fact, first of all there must be the participation and activeness of people who care about children, carry out socialization and counseling about children and are 
supported by the existence of people who want their area or city to be called child-worthy by prioritizing children. The most important. The community coordinates and synergizes in realizing their city that is worthy of children, and gets approval from the local government to make it a city that cares for children. (Roza \& Laurensius, 2018)

This is related to policies towards child-friendly city development (KLA), because the participation of the community has been stated in the Regulation of the State Minister for Women's Empowerment and Child Protection (Menneg PPPA) of 2011 with Number 13 concerning Guidelines for Development from KLA. In article 12 that the regulation states "The public and also the business world can play a role and participate as widely as possible in the development of KLA (Muntono \& Sri, 2017)

Participation from the community can support the formation of a child-friendly city, where in its implementation there are 3 elements that must be considered, namely the actors of the policy, the content of the policy and the last is the environment of the policy, referred to as the actor of the policy because of who will be responsible or as a stakeholder. and stakeholders as well as running so that a child-friendly city can be formed, of course there must be coordination with all related parties, programs, as well as the policy itself, the system and even the budget are also a concern in all processes of these activities.

The content or concept of the policy itself, must be in accordance with the existing criteria, the determination as a child-friendly city must clearly meet the standards or criteria that have been determined by the cluster or indicator set so that it can be called a child-friendly city, for example in the city that children have received birth certificates, and in giving it must be ensured that all children have received them, and if there are people who cannot afford to be given free birth certificates without being charged a single fee, because the provision of free certificates has fulfilled their rights. civilization and identity for children as a form of child protection. In addition, other indicators do not occur at a young age of marriage to children, all children receive education and teaching, as well as acts of violence, both physical and psychological, as well as sexual or economic neglect, do not exist, all acts of exploitation, violence do not occur in the city, and There is also an institution for child consultation and guidance, including good child care and care, guided and directed to understand and know how to guide and nurture and care for children and this consultation is introduced to the community, so that the community understands its aims and functions (Rumtianing, 2014)

An environment with a policy is defined as an environment that is indeed child-friendly, and provided a playground that is far from the crowd, vehicle fumes or vehicle pollution as well as cigarette smoke means that children cannot be allowed to smoke, even if someone wants to smoke, they are given a special room so that the smoke does not interfere. In line with this, with this convenience children can also go to school by pedaling a bicycle without fear of vehicles on the road and on foot by providing sidewalks that are free of obstacles, so that security on the road is not disturbed or disturbed by anyone.

Not only that, looking at the criteria and clusters that have been set, it can be said that the city is worthy of children, so the most important thing is to first build coordination and awareness in the community to realize how important the protection and fulfillment of children's rights is, even though there are parties parties involved in it are involved such as the business world and also the media, but without the support of the community, a child-friendly city cannot be formed, so it can be said that the community must play an active role and work together in building and educating the protection and health insurance. as well as access to education for children, and always protect children from all actions that would threaten their safety and endanger them, so that it can be said that a child-friendly city will be based on child-friendly and caring for children in the best interests of the child (Trihastuti, 2020).

\section{CONCLUSION}

1. The urgency of child protection in realizing a child-friendly city based on concepts and manifestations must be based on existing clusters and indicators, and supported by the participation of the community, and the business world as well as the media, where the media take over in reporting and broadcasting cities that are considered as worthy of children, and become a guideline or measure of other cities to participate in the success and care of the city and make the city the same city that is child-friendly and child-friendly as well

2. Children as a generation who will continue all the struggles and ideals of the nation, must be protected and fulfilled their rights and shunned from all acts of violence, both physical, psychological, sexual and child neglect, as well as actions in the form of child exploitation and parenting. wrong, but they must be given and pay attention to their rights in the form of education, health insurance and other protections.

\section{REFERENCES}

Holzscheiter, Anna, 2019. Jonathan Josefsson, Benght Sandin, Child Rights Governance : An Introduction, SAGE Journal, vol. 26

RozaDarmini, Laurensius Arliman S, 2018. Peran Pemerintah Daerah Untuk Mewujudkan Kota Yang Layak Anak Di Indonesia, Jurnal Hukum IUS OUIA IUSTUM No. 1 Vol. 25 
Rumtianing, Irma, 2014. Kota Layak Anak Dalam Perspektif Perlindungan Anak, Jurnal Pendidikan Pancasila dan Kewarganegaraan, Th. 27 No. 1

Said, Moh. Rohmad, Murtono dan Said dan Sri Utaminingsih, 2017. Implementasi Kota Layak Anak Di Kabupaten Demak, Jurnal REFLEKSI EDUKATIKA 8 (1)

Joni, Muhammad, Zulchaina Z. Tanamas, 1999. Aspek Hukum Perlindungan Anak Dalam Perspektif Konvensi Hak Anak, Bandung : Citra Aditya Bakti.

Hag, Muhammad Izzul, 2016. Qua Vadis Partisipasi Masyarakat Dalam Kebijakan Kabupaten Layak Anak (KLA) Sleman, APLIKASIA : Jurnal Aplikasi Ilmu-Ilmu Agama, Vol. 16 No. 2

Trihastuti, Nanik, Stephanie Apsari Putri, 2020. Reposition Of Child Protection Through The Enforcement Of Human Rights And Constitutional Rights, Jurnal Hukum dan Peradilan, Vol. 9, No. 2

Setyawati, Ratih, 2019. Pengelolaan Program Perlindungan Anak Terpadu Berbasis Masyarakat (PATBM), DIKLUS : Jurnal Pendidikan Luar Sekolah, Nomor 2 Volume 3

Saraswati, Rika, 2015. Hukum Perlindungan Anak Di Indonesia, Bandung : Citra Aditya Bakti

Fitriani, Rini, 2016. Peranan Penyelenggara Perlindungan Anak Dalam Melindungi Dan Memenuhi Hak-Hak Anak, Jurnal Hukum Samudra Keadilan, Vol. 11 No. 2

Waluyadi, 2009. Hukum Perlindungan Anak, Bandung : Mandar Maju

The 1945 Constitution

The Law Number 35 of 2014 is amended from Law Number 23 of 2002 concerning Child Protection 